\title{
実験的平衡側咬頭干渉が顎機能に及ぼす影響
}

\author{
馬 場 一 美

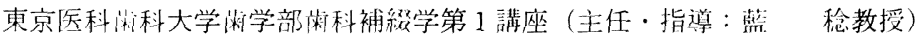 \\ （1990年12月20日 受付）
}

\section{Influences of Balancing-side Interference on Jaw Function}

\section{Kazuyoshi Baba}

The First Department of Prosthodontics, Faculty of Dentistry,

Tokyo Medical and Dental University

(Chief and Director : Prof. Minoru Ai)

The influences of experimental balancing-side interference on the jaw function were investigated on 6 subjects. A specially designed onlay was fabricated for the lower second molar, which acted as an artificial balancing-side interference in the lateral mandibular position. The subjects were asked to do maximum clenching, lateral gliding and gum chewing with and without the device. Electromyographic activity of the masseter and the anterior and posterior temporal muscles were measured and the related mandibular movement was simultaneously recorded during these tasks.

Introduction of the experimental interference caused alteration in the muscle activity as follows :

1. When the subjects exerted maximum clenching efforts in the lateral mandibular position, the ratio of the temporal muscle activity on the working-side to the balancing-side decreased, while that of the masseter muscle remained unchanged.

2. There was a tendency for the activity in the working-side posterior temporal muscle to increase during gliding from intercuspation. The ratio of the temporal muscle activity on the working-side to the balancing-side decreased during gliding into intercuspation.

3. Prolongation of the occlusal phase associated with the increase of the muscle activity was observed during gum chewing on the side opposite to the interference.

It was suggested that the balancing-side interference might provoke a specific muscle activity in the temporal muscles during parafunctional clenching or grinding.

\section{I. 粕言}

咬頭干涉は顎機能異常の局所的因子の一つにあ げられているが，とくに側方滑走運動時の平衡側 の咬頭干渉については早くから注目され，多数㛟 討されてきた。Schuyler ${ }^{1)}$ は臼歯部での平衡側接
触による外傷性の作用は顎関節にまで及ぶ可能性 があることを指摘し， Ramfjord ${ }^{2)}$ は顎機能異常 患者の闒口筋活動に平衡側 咬頭干渉が原因と考 えられる異常な状態を観察している。また，中 村 ${ }^{3)}$, 関4), Posselt ${ }^{5)}$, Shore ${ }^{6)}$ らは平衡側咬頭干 渉は，顎機能異常患者にみられる咬合異常のなか 
で多く認められるものの一つであることを報告し ている。このような力学的考察, 生理学的観察, 疫学的調査に基ついて平衡側咬頭干渉の顎機能異 常に対する関連づけが行われてきた。

一方，そのメカニズムを解明することを目的 に, Schaerer ${ }^{7}$, De Boever ${ }^{8)}$, Belser ${ }^{9)}$ らは健常 者の咬合関係を人為的に变化させ，実験的な平衡 側咬頭干涉の咀嚼筋活動への影響を検討してい る。咀嚼時の筋活動を検討した Schaerer や De Boever は, 平衡側咬頭干渉が閉口時の閉口筋活 動を一時的に抑制することを明らかにしている。 側方咬合位での咬又しめ時の筋活動を娭討した Belser は, 平衡側咬頭干渉が平衡側側頭笳の活 動を増大させることを示している。

この他，多くの検討が行われているにもかかわ らず，平衡側咬頭干渉の筋機能に対する作用機序 は十分解明されてはいない。

臨床的にしばしば観察され, 顎機能異常の因子 と考えられる平衡側咬頭干渉の多くは, 作業側の ガイドや咬合薢曲の変化に伴って生じ，側方滑走 運動過程のある段階で作業側の咬合接触を失わせ るものである10)。したがって，平衡側咬頭干渉に 関する検討を行う場合，その人工的咬頭干涉の付 与にあたって，当該䨑のみを形態変更する方法で は，与える干渉の程度に限界がある。また，咬頭 嵌合位の咬合高径を変えるような方法では，側方 咬合位での咬みしめのみの検討にとどまらざるを 得ない。元のためか，側方滑走運動時の平衡側咬 頭干渉に関する研究はみあたらない。

そこで，本研究では咬頭嵌合位を変更すること なく，側方滑走運動時に他の上下顎歯を離開させ るような平衡側咬頭干渉装置を製作し，側方咬合 位での咬みしめ，側方滑走運動および咀嚼運動を 行わせて，閉口筋活動および下顎運動を記録測定 し, 平衡側の咬頭干渉が顎機能にどのような影響 を及ぼすかを検討した。

\section{II. 研究方法}

側方咬合位において平衡側の咬頭干涉となるよ らに，被験者の下顎第二大臼歯に実験的な干涉装
表 1 各被駼者の側方咬合㴍式, 咀嚼喈好側 および処置蔽

\begin{tabular}{|c|c|c|c|}
\hline 被験者 & 側方咬合様式 & 咀嚼嘫好側 & 処置雨 \\
\hline A & \begin{tabular}{l|l}
32 & 3 \\
32 & 3
\end{tabular} & 右 & $\overline{7}$ \\
\hline B & \begin{tabular}{l|l}
3 & 3 \\
3 & 3
\end{tabular} & 右 & $\overline{7}$ \\
\hline C & \begin{tabular}{l|l|l}
3 & 3 \\
3 & 3
\end{tabular} & 右 & $\overline{7}$ \\
\hline D & \begin{tabular}{l|l}
3 & 3 \\
3 & 3
\end{tabular} & 右 & $\overline{7}$ \\
\hline E & \begin{tabular}{l|l}
43 & 3 \\
43 & 3
\end{tabular} & 右 & $\overline{7}$ \\
\hline F & \begin{tabular}{l|l|l}
3 & 3456 \\
3 & 356
\end{tabular} & 左 & $\overline{71}$ \\
\hline
\end{tabular}

置を付与し，側方咬合位での最大咬みしめおよび 側方滑走運動を行わせて筋活動を, またガム咀嚼 を行わせて筋活動と下顎運動を記録測定して, 実 験的咬頭干渉との関係を検討した。さらに，作業 側の犬䨑部と第二大臼歯部にも実験的に強い咬合 接触を与兄, 同様に筋活動, 下顎運動を記録測定 し検討した。

\section{1. 被験者}

被験者はいずれも顎口腔系に異常が認められず 個性正常咬合を有し，非咀嚼嗜好側の下顎第二大 臼歯に歯冠修復処置を必要とした成人男子 6 名で ある。各被験者の側方咬合様式, 咀嚼䅉好側拈よ び処置歯を表 1 亿示す。

\section{2. 作業側および平衡側咬頭干涉装置, 上領犬雪舌面 装置}

本研究では平衡側咬頭干涉装置を装着すること により，側方咬合時に平衡側の第二大臼歯部に作 業側よりも強い接触関係を与えた。同干渉装置は 図 1-A，2-Aに示寸よらに被験運動に対応して 2 種類の形態のものを製作し，それぞれを側方咬 合位での咬みしめ時と, 側方滑走運動およびガム 阻嚼時に用いた。雨装置の違いは，前者では咬 頭嵌合位の高径が変わるが，後者では変わらない 


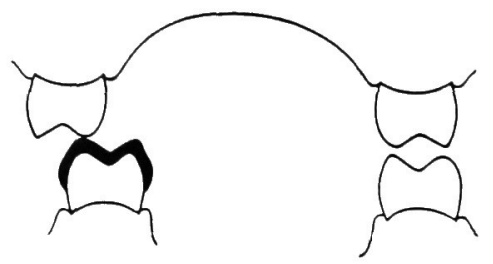

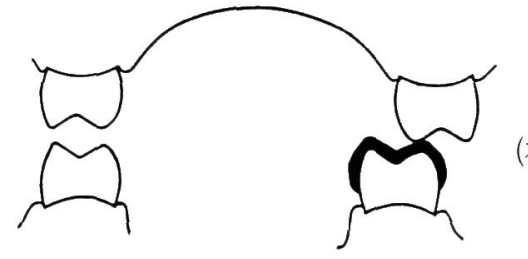

A 平衡側咬頭干涉装置
(左側方咬合位)

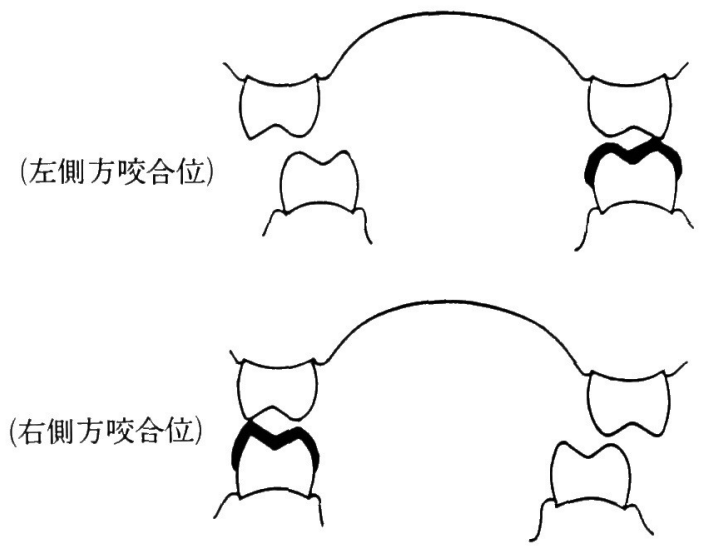

B 作業側咬頭干涉装置

図 1 作業側および平衡側咬頭干涉装置（咬みしめ用）

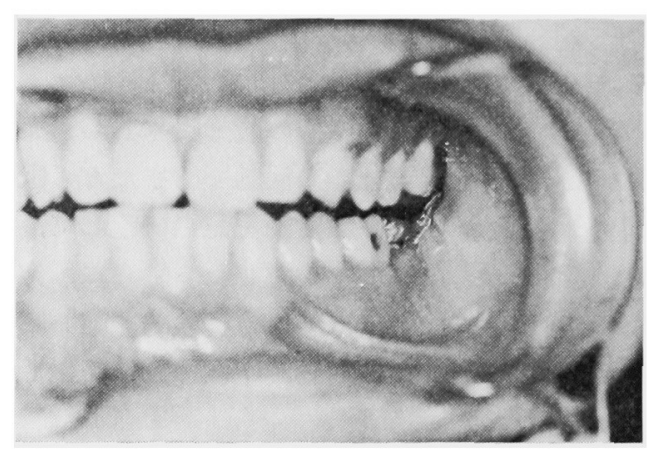

(右側方咬合位)

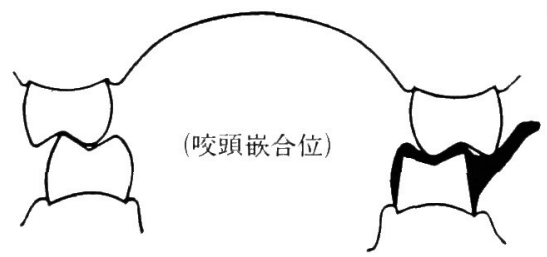

(咀椨㖺好側)

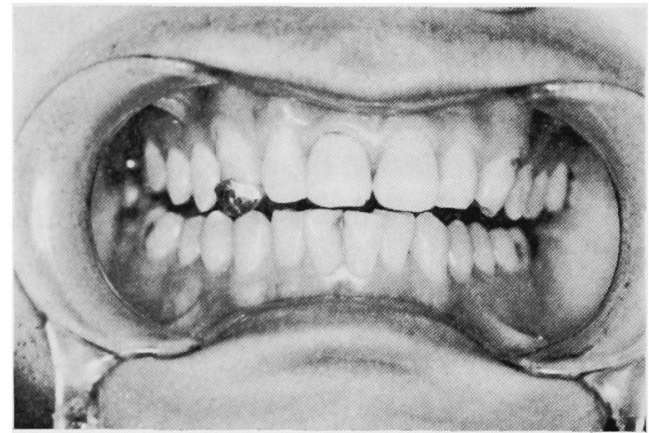

B 上顎犬米舌面装置

\section{A 平衡側咬頭干涉装置}

図 2 平衡側咬頭干涉装置（側方滑走運動およびガム咀嚼用）打よび上顎犬阙舌面装置

ことである。しかし，両装置とも側方咬合位での 咬合高径を本来の位置よりも増加させてしまうた め, 測定結果にその影響が現れることが予想され る。そこで, 平衡側咬頭干涉のみの影響をとら兄 るために，側方咬合位での咬合高径をこの干渉と 同程度增加させる装置を，作業側犬歯および作
業側第二大臼雨に，それぞれ上顎犬歯舌面装置沶 よび作業側咬頭干涉装置として製作し，此較対照 とした。

それらの製作方法は以下のごとくである。

被験者の下顎第二大臼歯に対して支台形成を行 い，印象採得し，歯列模型を製作したのち，顔弓 
を使用してこれを半調節性咬合器(ディナー社製, ディナーMK 2) に装着した。チェックバイトに より顆路の調整を行い, さらに切歯指導板の傾斜 を側方滑走運動時に天然歯の場合よりも $10^{\circ}$ 急に なるよらに調整した。

1）作業側㧍よび平衡側咬頭干渉装置（咬久し め用)

まず支台形成した歯に通常の形態の金銀パラジ ウム合金による暫間補経物を製作したのち，前述 の咬合器上で作業側犬歯が尖頭対尖頭となる位置 で，左右側下顎第二大四歯に図 1 亿示すような形 状の 2 種類のアンレーを金銀パラジウム合金で製 作し，それぞれを作業側扣よび平衡側咬頭干涉装 置（WCおよび BC）とした。これらの装置は， 装着すると咬合高径が大きくなり咬頭嵌合位が再 現できなくなるため，側方咬合位での咬みしめ時 のみに使用した。

2）平衡側咬頭干渉装置（側方滑走運動および ガム咀嚼用）および上顎犬歯舌面装置

前述の支台形成を行った下顎第二大臼歯に対し て, 同一咬合器上で咀嚼嗜好側への側方運動をさ せたときに，対合する上顎大曰歯頓側咬頭の遠心 斜面と接触滑走するように，被蓋関係が逆になる 形状のアンレーを金銀パラジゥム合金で製作し， これを平衡側咬頭干涉装置（BC）とした（図 2A)。

また,このアンレーを装着した場合と可及的に 同じ側方滑走運動ができるような装置を作業側上
顎犬歯に対し金銀パラジゥム合金で製作し，上顎 犬歯舌面装置（舌面装置）とした（図 2-B)。 な拈，両装置を口腔内に装着し，咬頭嵌合位の 位置が変わらないよう調整した後，シロナソグラ フ（シーメンス社製）を用いて円滑な滑走運動が 行えることを確認した。あわせて側方滑走運動路 の矢状面に対する傾斜角度を前頭面拉よび水平面 の各投影上で求めた（図 3 , 表 2 )。

表 2 側方滑走運動路の前頭面および水平面投影角

\begin{tabular}{|c|c|c|c|c|}
\hline 被験者 & \multicolumn{2}{|c|}{$\begin{array}{c}\text { 前頭面投影角 } \\
\text { (度) }\end{array}$} & \multicolumn{2}{|c|}{$\begin{array}{c}\text { 水平面投影角 } \\
\text { (度) }\end{array}$} \\
\hline \multirow{3}{*}{ A } & 66 & \multirow{3}{*}{$\begin{array}{l}(-9) \\
(-12)\end{array}$} & 76 & \multirow{3}{*}{$\begin{array}{l}(-2) \\
(-3) \\
\end{array}$} \\
\hline & 57 & & 74 & \\
\hline & 54 & & 73 & \\
\hline \multirow{3}{*}{ B } & 54 & \multirow{3}{*}{$\begin{array}{l}(-14) \\
(-13)\end{array}$} & 84 & \multirow{3}{*}{$\begin{array}{l}(13) \\
(14)\end{array}$} \\
\hline & 40 & & 97 & \\
\hline & 41 & & 98 & \\
\hline \multirow{3}{*}{ C } & 46 & \multirow{3}{*}{$\begin{array}{l}(-7) \\
(-7)\end{array}$} & 63 & \multirow{3}{*}{$\begin{array}{r}\left(\begin{array}{r}22 \\
(\end{array}\right) \\
(\quad 8) \\
\end{array}$} \\
\hline & 39 & & 85 & \\
\hline & 39 & & 71 & \\
\hline \multirow{3}{*}{$\mathrm{D}$} & 40 & \multirow{3}{*}{$\begin{array}{l}(-6) \\
(-8)\end{array}$} & 69 & \multirow{3}{*}{$\begin{array}{l}(13) \\
(\quad 10) \\
\end{array}$} \\
\hline & 34 & & 82 & \\
\hline & 32 & & 79 & \\
\hline \multirow{3}{*}{$E$} & 71 & \multirow{3}{*}{$\begin{array}{l}(-16) \\
(-17)\end{array}$} & 71 & \multirow{3}{*}{$\begin{array}{l}(-8) \\
(-9) \\
\end{array}$} \\
\hline & 55 & & 63 & \\
\hline & 54 & & 62 & \\
\hline \multirow{3}{*}{$\mathrm{F}$} & 50 & \multirow{3}{*}{$\begin{array}{l}(-11) \\
(-13)\end{array}$} & 92 & \multirow{3}{*}{$\begin{array}{l}1) \\
6\end{array}$} \\
\hline & 39 & & 93 & \\
\hline & 37 & & 98 & \\
\hline
\end{tabular}

上段：装置装着前 中段：B C 装着時

下段：舌面装置装着時

右列（）：装置装着前との差

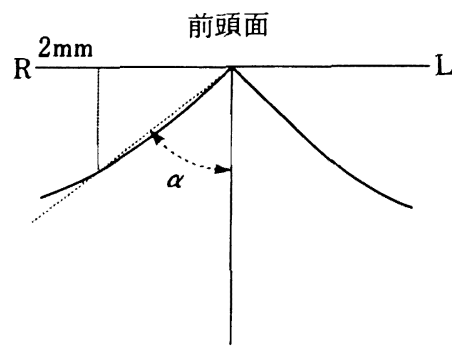

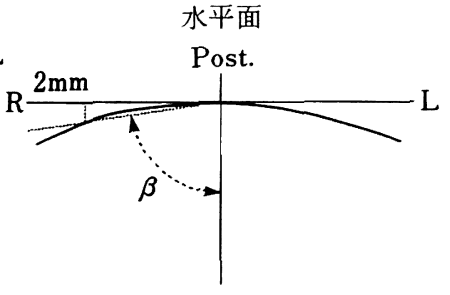

Ant.

\section{$\alpha$ : 前頭面投影角 \\ $\beta:$ 水平面投影角}

図 3 側方滑走運動路の前頭面および水平面投影角の測定部位 
これらの装置は側方滑走運動およびガム咀㗖時 に使用したが，舌面装眻は側方咬合位での咬みし め時にも使用した。また， BC 非装着時，および 側方咬合位での咬みしぬ時には，支台形成した歯 については常にさきの暫間補経物を装着した状態 で実験を行った。

\section{3. 筋電図記録装置}

1）被験筋扣よび導出方法

対象とした被験筋および部位は, 左右咬筋浅部 (M), 左右側頭筋前部 (AT) および左右側頭筋 後部 $(\mathrm{PT})$ の 6 筋である。導出方法は皮虞用表 面電極（Beckman社製）を用いた双極導出とし， 電極は極間距離 $15 \mathrm{~mm}$ で筋の走行と平行になる ように固定し、アース電極は両耳梁に貼付した。 なお，電極間抵抗をできるだけ下げるために，電 極の固定の前に皮䖉前処理材（スキンピュア，日 本光電社製）とアルコールにより皮虞を十分に清 拭した。

2）増幅

表面電極により導出した筋活動電位は生体電気 現象用増幅器 (1253A 型, 日本電気三栄社製) に より増幅した。増幅器の時定数は $0.03 \mathrm{sec} と し$,

$1 \mathrm{kHz}$ のハイカットフィルターを介在させた。増 幅度は $500 \mu \mathrm{V}$ の入力に対して感熱型オムニュー ダ ( $8 \mathrm{MI} 4$, 日本電気三栄社製) の振れが $10 \mathrm{~mm}$ になるようにした。

なお, 増幅器からの出力はいったんデータレコ ーダ（KS-616型，ソニーマグスケール社製）に 収録し，その後 12 ビット $\mathrm{A} / \mathrm{D}$ コンバータ (DRA $10 \mathrm{~A}$, 東京測器制）によりサンプリングタイム 1 $\mathrm{msec}$ で $\mathrm{A} / \mathrm{D}$ 変換後, パーソナルコンピュータ （PC-9801VX，日本電気社製）上で全波整流し平 滑化処理した。

\section{4. 下䫟運動記録装置}

側方滑走運動およびガム咀嚼時の下顎運動は筋 活動と同時にシロナソグラフを用いて下顎切柬点 部で三次元的に記録した。シロナソグラフの信号 はシロナソグラフ・アナライジングシステムII （カノープス社製）を用いて保存するとともに， いったんデータレコーダに収録した後， A/D I

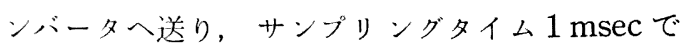
A / D 変換し, 平滑化処理後, 筋電信号とともに 保存した。な拉, シロナソグラフのアンテナ部は 咬合平面に平行になるよらに設定した。他の設定 は通法に従った11)。

\section{5. 実験方法}

被験者を歯科用治療椅子に掛けさせ, フランク フルト平面が水平となるよらに頭位を調整し, 装 置装着前および各装置装着状態で以下の運動を行 わせた。

なお，作業側および平衡側咬頭干涉装置の装着 にはユージノール系セメント（ユージダイン，昭 和薬品化工社製）を，喑面装置の装着にはシア， アクリレート系接着剤（アロンアルファ，東亜合 成化学社製）を用い，装置の装着順序が実験結果 に影響を及ぼさないように, 装着する順序はラン ダムとた。

1）側方咬合位での最大咬みしめ

まず，装置を装着しない状態で，咬頭嵌合位 (IP) および犬歯が 尖頭対尖頭となる左右の側方 咬合位で最大咬みしめを行わせた。続いて，各装 置を装着させて側方咬合位において最大咬みしめ を行わせた。なお，側方咬合位での咬みしめは， $\mathrm{BC}$ および WC 装着時には左右両側で, 舌面装置 装着時では咀嚼嗜好側でのみ行わせた。

各咬みしめは 2 秒間ずつ 5 回行わせ, 疲労によ る影響をさけるため, 各咬みしめの間に 3 分間, また装置の交換時には 5 分間の休憩をとった。

2）側方滑走運動およびガム咀嚼

まず，装置を装着しない状態で，咀嚼嗜好側へ の往復側方滑走運動および左右側を指示してガム 咀嚼を行わせた。続いて BC および舌面装置を 装着させて, 側方滑走運動和よびガム咀嚼を行わ せた。

なお，側方滑走運動は中程度の咬合圧を加えな がら, IP と犬霜が尖頭対尖頭となる側方咬合位 との間で20秒間行うこととし, 運動速度はメト口 ノームに従って毎分80往復と規定した。ガム咀嚼 は, 十分に軟化した状態になったチュウインガム （ロッテ社製,フリーゾーン）の咀嚼を，咀嚼側 
A 側方滑走運動

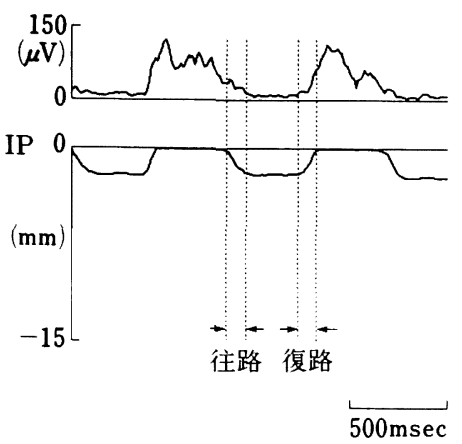

B ガム咀㗖

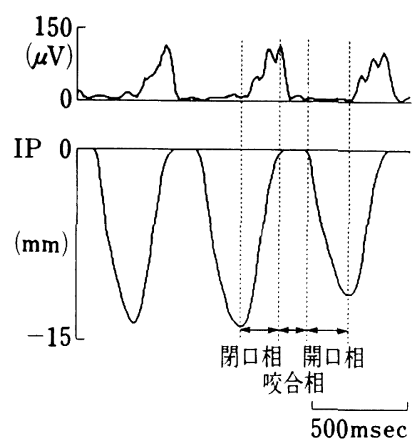

上：整流，半滑化処理後の筋活動電位

下：平滑化処理後の下顎運動の垂直成分

図 4 筋活動の分析区間

表 3 各筋 $の$ IP 比

各筋のIP 比 $=$ 各被験運動時の各筋の積分筋活動量 $(1$ 秒間当たり)

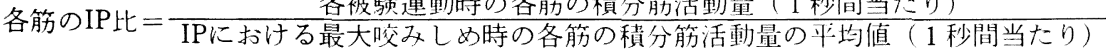

のみを指定し任意の速度で30秒間行わせた。

\section{6. 測定結果の分析}

1) 筋活動

筋活動の定量化には積分值を用い, ハーソナル コンピュータ上で以下の分析を行った。

(1) 最大咬みしめ

2 秒間の各咬みしめのうち，筋活動が安定した 0.5 秒間の筋活動の積分值を求めた。

(2) 側方滑走運動

滑走運動が安定したと思われる10往復路の各ス トロークについて，下顎運動の垂直成分より IP から側方咬合位までの往路運動相（往路）と，側 方咬合位から IP までの復路運動相（復路）とを 識別し，各相に拈ける筋活動の積分值を求めた

(図 4-A)。

(3) ガム咀嚼

咀嚼開始後 5 ストローク以降の 15 ストロークの おのおのについて周期時間を求め, さらに下顎運 動の垂直成分より閉口相，咬合相および開口相の 3 相に分け，各相の時間および閉口相と咬合相に
おける筋活動の積分值を求めた（図 4-B)。

得られた積分值はすべて 1 秒間あたりの值に換 算した。さらに IP での最大咬みしめ時に得られ た值の平均値を 1.00 として，それに対する各被験 運動時に得られた值の割合を求め，それを IP 比 とし，各筋の IP 比を求めた12 14)（表 3 ）。

また，作業側と平衡側の筋活動の大小関係を娭 討するために，同名筋の IP 比を左右で加光，そ のなかでの作業側筋の IP 比の百分率を求め，そ れを作業側の活動比率とした。 $\mathrm{M}, \mathrm{AT}$ 抢よび $\mathrm{PT}$ についてそれぞれ作業側の活動比率を求めた（表 $4)$ 。

さらに，IP 比および作業倒の活動比率につい て，(1)の最大咬みしめでは 5 回分の平均值を，(2) の側方滑走運動では10ストロークの平均值を，そ して(3)のガム咀嚼では15ストロークの平均值を求 めた。

2）下顎運動

ガム咀嚼時の下顎湩動路について，シロナソク ラフ・アナライジシグシステム $\|$ を朋いて， IP 


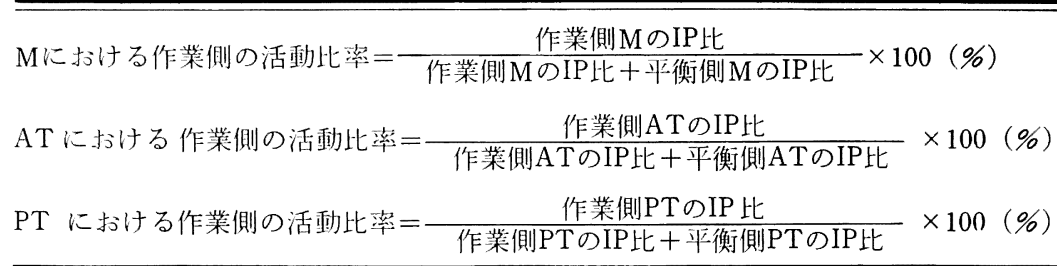

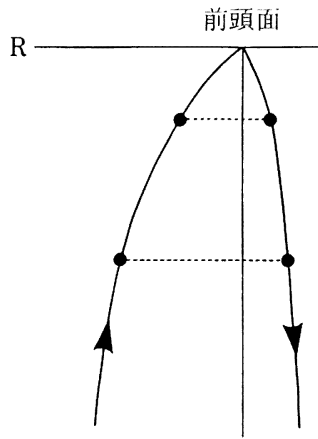

閉口路
開口路

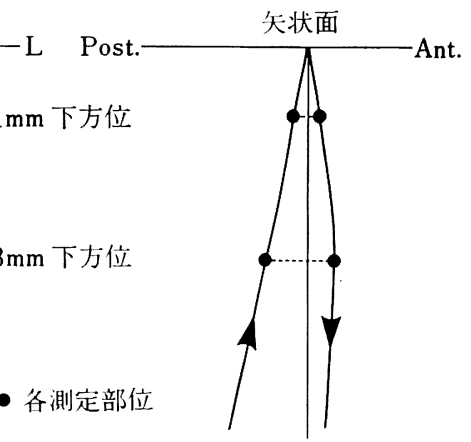

閉口路 開口路

図 5 ガム阻嚼時の下顎運動の測定部位

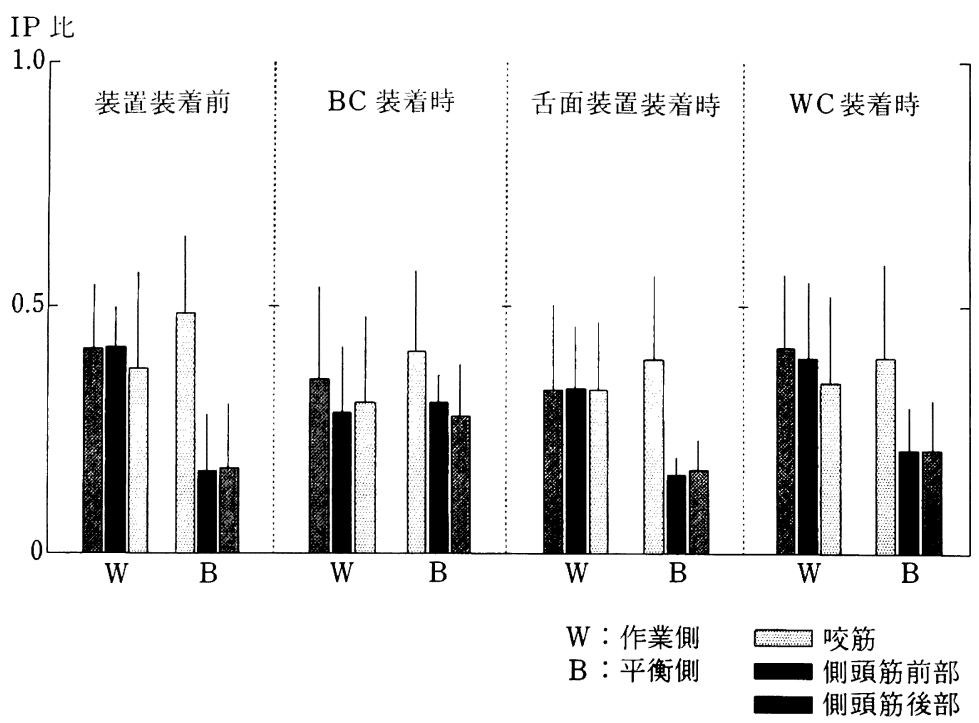

図 6 側方咬合位での最大咬みしめ時の各筋のIP比（全例平均）

より $1 \mathrm{~mm}$ 抢よび $3 \mathrm{~mm}$ 下方位に拈ける閉口路 と開口路の三次元的な位置関係を検討した（図 $5)$ 。
各装置の筋活動拈よび下顎運動への影響を調べ るため，以上の分析値について “ $\mathrm{t}$ 検定”を用い て有意水準 $5 \%$ で差の検定を行った。 


\section{III. 研 究 結果}

\section{1. 側方咬合位での最大咬みしめ}

1）各筋の IP 比

図 6 亿装置装着前, $\mathrm{BC}$ 装着時, 舌面装置装着 時, WC 装着時の各筋の IP 比の全例平均を示す。 平均値は装置装着前, $\mathrm{BC}$ 装着時执よび $\mathrm{WC}$ 装着 時では 6 被験者の左右つまり 12 例の, 舌面装置装 着時では 6 例の平均である。

装置装着前には Mの IP 比は作業側で $0.39 \pm$ 0.19 , 平衡側で $0.49 \pm 0.18$, AT の IP 比はそ れぞれ $0.42 \pm 0.14,0.16 \pm 0.07, \mathrm{PT}$ の IP 比は それぞれ $0.41 \pm 0.19,0.16 \pm 0.11$ であった。

BC を装着すると IP 比は，平衡側の AT 扣よ び PTで有意に増加する傾向が認められたが，他 ではすべて減少し，とくに平衡側Mと作業側 $\mathrm{AT}$ において有意に減少した。被験者別にみると作業 側のM抢よび PTに打いても減少傾向を示すもの が多かったが，増加傾向を示すものも認められ， 全体として及ると一定の傾向は認められなかっ た。

舌面装置装着時の各筋の IP 比は, 装着前と比 較すると多くの被験者に打いて減少したが，減少 傾向を示す筋は被験者によって異なり，全体とし てみると平衡側 $\mathrm{M}$ の減少傾向のみに有意差が認め られた。

WC 装着時の IP 比は，装着前と比較すると両 側 $\mathrm{M} て ゙$ 減少し，平衡側 $\mathrm{AT}$ で増加するものが多か ったが，全体としてみると平衡側Mの減少傾向の みに有意差が認められた。

2）作業側の活動比率

図 7 はATに扮ける作業側の活動比率の全例平 均を示す。

AT に打石作業側の活動比率は, 装置装着前

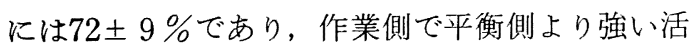
動を示したが，BC 装着後， $50 \pm 9 \%$ と有意に 減少し, 作業側, 平衡側の両側で同程度の活動を 示すようになった。被験者別にみても全12例で減 少し，そのらち10例で有意差が認められた。舌面 装置拈よびWC装着時の作業側の活動比率と装着

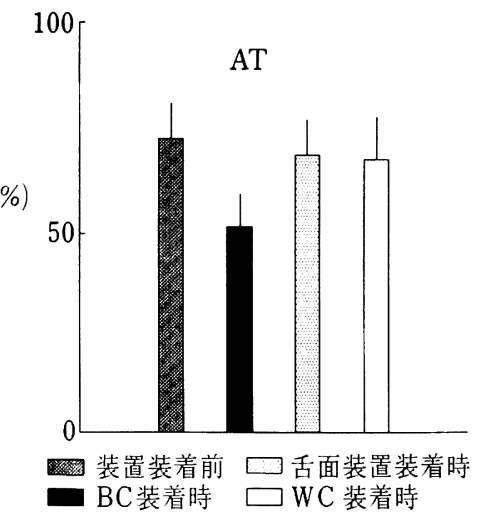

闵 7 側方咬合位での最大咬みしめ時の作業側の 活動比率 (全例平均)

前のそれとの間には有意差は認められなかった。 また $\mathrm{BC}$ 装着時と，舌面装置および WC 装着時 とを比較しても，いずれの場合も $\mathrm{BC}$ 装着時のほ うが有意に小さく， $\mathrm{BC}$ 装着時のみが他の状態と 暴なる傾向を示した。

PTでもAT と同様， BC を装着すると作業侧 の活動比率は有意に減少したが，被験者別にみる と増加傾向を示すものも2 例認められ，そのらち 1 例では有意差が認められた。また， BC 装着時 と舌面装置抒よび WC 装着時との間には有意差 は認められず， $\mathrm{BC}$ 装着による作業側の活動比率 の減少傾向はAT ほど顕著ではなかった。

Mに扮ける作業側の活動比率は, 装置装着前に は $42 \pm 12 \%$ であり， BC 装着時，舌面装置装着

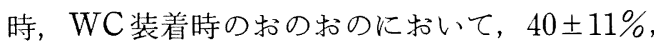
$45 \pm 7 \%, 46 \pm 15 \%$ となったが，いずれの間にも 有意差は認められなかった。

\section{2. 側方滑走運動}

1）各筋の IP 比

(1) 往路

図 8-Aは典型例と思われる被験者 $\mathrm{E}$ の装置装 着前, $\mathrm{BC}$ 装着時および舌面装置装着時における 各筋の IP 比を示す。

往路では装置装着前, $\mathrm{BC}$ 装着時, 舌面装置装 着時のいずれの場合にも作業側 PTが最大值を示 

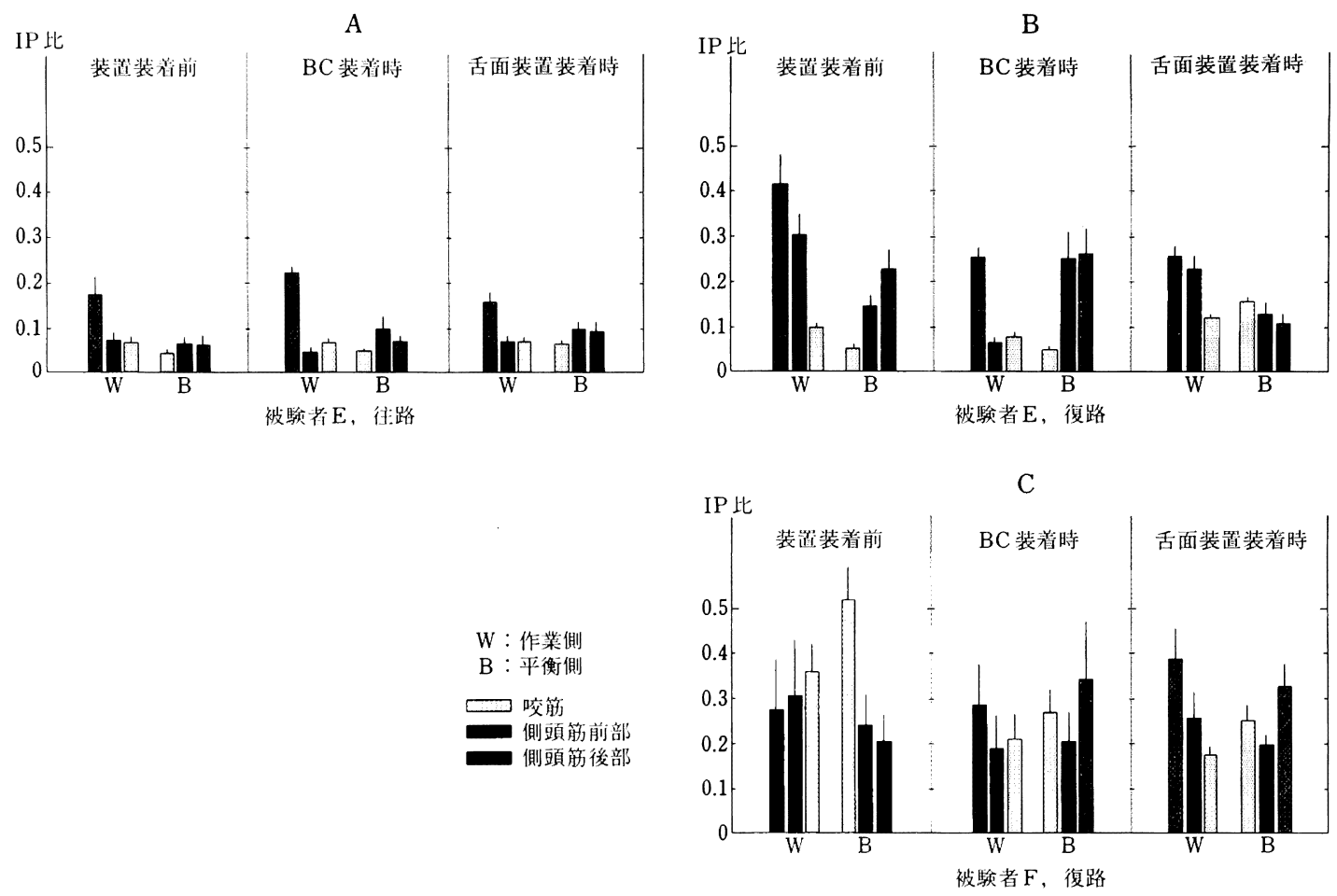

図 8 側方滑走運軼時の各筋のIP比

すことが多く, 同様の傾向は被験者 B の装置装着 前招よび舌面装置装着時と, 被験者 $\mathrm{D}$ の舌面装置 装着時を除く全例に抏いて認められた。

また，作業側 PT の IP 比は，BCを装着すると 被験者 $\mathrm{F}$ を除く 5 例で被験者 $\mathrm{E}$ と同様に有意に増 加し，舌面装置を装着すると被験者 $\mathrm{A} ， \mathrm{D}$ におい て減少したが，他の被験者では有意な変化は認め られなかった。

他の 5 筋の BC および舌面装置を装着したとき の変化は被験者により異なり, 一定の傾向は認め られなかった。

(2) 復路

図 8-B，8-C は典型例と思われる被験者 $\mathrm{E}$, Fの各筋の IP 比を示す。

復路では, 被験者 $\mathrm{E}$ の平衡側 $\mathrm{M}$ の活動は小さか ったが，その他の被験者では，装置装着前， $\mathrm{BC}$ 装着時, 舌面装置装着時のいずれの場合にも, 各 筋において活発な活動が認められた。
往路と比較すると, 作業側 PT の IP 比は, 被

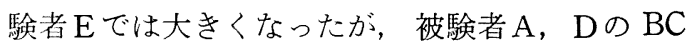
装着時には逆に小さくなった。その他の 5 筋の IP 比は，いずれの被験者でも復路において往路 より大きくなる傾向が認められた。

$\mathrm{BC}$ および舌面装置装着時の各筋の IP 比を装 䈯装着前と比較すると, 作業側 Mの IP 比は, BC を装着すると被験者 $\mathrm{E}, \mathrm{F}$ と同様, ほとんどの被 唡者に打いて減少し, そのうち4例で有意差が認 められた。舌面装置装着時の変化は, 被験者によ り異なり一定の傾向は認められなかった。

平衡側 Mの IP 比は, $\mathrm{BC}$ を装着すると被験者 $\mathrm{D}$ 抢よび Fにおいて有意に減少したが，他の被験 者では有意な変化は認められなかった。舌面装置

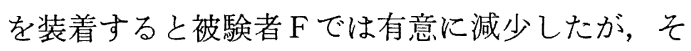
の他の 4 例では逆に增加し有意差が認められた。

作業側 ATの IP 比は， BC を装着すると減少 傾向を示すものが多く，そのらち被験者 $\mathrm{E}$ および 


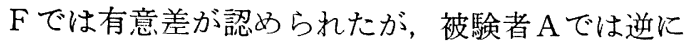
增加傾向を示した。舌面装置装着時の変化には被 験者 $\mathrm{E} て ゙$ 有意差が認められたが，そらした変化を 示すものは少なかった。

平衡側 ATの IP 比は， BC を装着すると被験 者Fでは減少したもののその他の 5 例では増加 し，そのらち4例で有意差が認められた。舌面装 置装着時では被験者 B の増加傾向のみに有意差が 認められた。

作業側 PT の IP 比の BC および舌面装置装着 時の変化は被験者により異なり,一定の傾向は認 められなかった。

平衡側 PT の IP 比は, BC を装着すると被験 者 $\mathrm{E}, \mathrm{F}$ と同様に 5 例で増加し, そのうち 4 例で 有意差が認められた。舌面装置装着時の変化は被 験者により異なり，一定の傾向は認められなかっ た。

2）作業側の活動比率

(1) 往路

図 9-AはPT に括ける作業側の活動比率の全 例平均を示す。

$\mathrm{PT} に お け る$ 作業側の活動比率は，装着前に60 $\pm 7 \%$ であり, 作業側で平衡側より強い活動を示 す傾向が認められた。 $\mathrm{BC}$ 抢よび舌面装置を装着 するとそれぞれ $66 \pm 8 \% ， 56 \pm 5 \%$ となり， BC 装着時に最大となる傾向が認められた。被験者別
(\%)

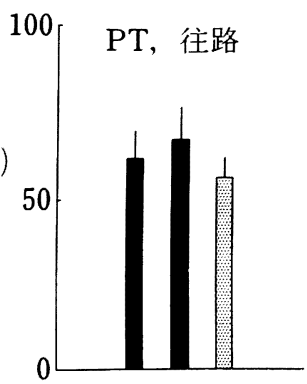

A

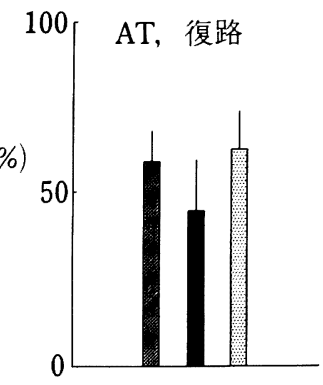

B

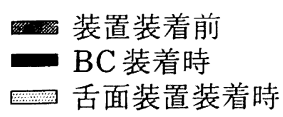

図 9 側方滑走運動時の作業側の活動比率（全例 平均)
にみると， $\mathrm{BC}$ を装着すると被験者 $\mathrm{F}$ を除く 5 例 で增加し，そのうち 3 例で有意差が認められた。 舌面装置を装着すると被験者 $\mathrm{E} ， \mathrm{~F}$ で有意減少 したが，他の被験者では有意な変化は認められな かった。また， $\mathrm{BC}$ 装着時と舌面装置装着時とを 比較すると， 5 例で $\mathrm{BC}$ 装着時のほうが大きい 值を示し，そのらち4 例では有意差が認められ た。

M拉よびATに拈ける作業側の活動比率の $\mathrm{BC}$ および舌面装置装着時の变化は被験者により異な り，一定の傾向は認められなかった。

(2) 復路

図 9-BはATに拈ける作業側の活動比率の全 例平均を示す。

AT に扮ける作業側の活動比率は，装置装着前 に $59 \pm 7 \%$ であり， BC を装着すると $45 \pm 13 \%$ 一 と有意に減少した。舌面装置装着時には $63 \pm 10 \%$ となり， BC 装着時に招いて最小となる傾向が認 められた。被験者別にみても BC を装着すると全 例で減少し，そのうち 4 例で有意差が認められ た。舌面装置装着時には有意な変化を示するのは 少なかった。また $\mathrm{BC}$ 装着時と舌面装置装着時と を比較すると, 全例で BC 装着時の流うが小さい 值を示した。

PTに和ける作業側の活動比率は，装置装着前 に $58 \pm 3 \%$ であり，BC を装着すると $52 \pm 6 \%$ と減少した。舌面装置装着時には $60 \pm 7 \%$ とな り， $\mathrm{AT}$ と同様 $\mathrm{BC}$ 装着時において最小となる傾 向が認められた。被験者別にみると，BCを装着 すると 6 例中 5 例で減少し，そのらち 3 例で有意 差が認められた。舌面装置を装着すると 2 例で有 意に增加したが，他の被験者においては有意な変 化は認められなかった。

Mに括ける作業側の活動比率は, 装置装着前に $54 \pm 8 \%$ であり， BC 打よび舌面装置を装着する とそれぞれ $50 \pm 7 \% ， 48 \pm 6 \%$ となった。被験者 別にみると， BC を装着すると 4 例で有意に減少 し，舌面装置を装着しても 2 例で減少したが，い ずれの場合も他の被験者では有意な変化は認めら れなかった。 
表 5 ガム咀嚼時の各相および周期時間

\begin{tabular}{|c|c|c|c|c|c|}
\hline 被験者 & 夹 䮖 条 件 & 閉口相 & 咬含相 & 開口相 & 周期時間 \\
\hline \multirow{3}{*}{ A } & 装置装着前 & 0.143 & 0.268 & 0.185 & 0.595 \\
\hline & B C 装着時 & 0.163 & 0.273 & 0.181 & 0.617 \\
\hline & 舌面装置装着時 & 0.151 & 0.255 & 0.171 & 0.577 \\
\hline \multirow{3}{*}{ B } & 装置装着前 & 0.287 & 0.189 & 0.310 & 0.785 \\
\hline & B C 装着時 & 0.367 & 0.239 & 0.334 & 0.941 \\
\hline & 舌面装置装着時 & 0.332 & 0.202 & 0.296 & 0.830 \\
\hline \multirow{3}{*}{ C } & 装置装着前 & 0.158 & 0.185 & 0.251 & 0.594 \\
\hline & B C 装着時 & 0.172 & 0.205 & 0.260 & 0.637 \\
\hline & 舌面装置装着時 & 0.152 & 0.193 & 0.198 & 0.543 \\
\hline \multirow{3}{*}{$\mathrm{D}$} & 装置装着前 & 0.167 & 0.140 & 0.215 & 0.521 \\
\hline & B C 装着時 & 0.159 & 0.190 & 0.210 & 0.559 \\
\hline & 舌面装置装着時 & 0.190 & 0.179 & 0.208 & 0.577 \\
\hline \multirow{3}{*}{$\mathrm{E}$} & 装置装着前 & 0.220 & 0.177 & 0.257 & 0.654 \\
\hline & B C 装痻時 & 0.206 & 0.188 & 0.239 & 0.633 \\
\hline & 舌面装置装后時 & 0.230 & 0.167 & 0.282 & 0.679 \\
\hline \multirow{3}{*}{$\mathrm{F}$} & 装置装着前 & 0.147 & 0.150 & 0.122 & 0.419 \\
\hline & B C 装着時 & 0.206 & 0.152 & 0.142 & 0.500 \\
\hline & 舌面装置装着時 & 0.157 & 0.140 & 0.129 & 0.426 \\
\hline
\end{tabular}

\section{3. カ公咀魦}

ガム咀嚼は咀嚼側を指定し左右両側で行わせた が，嘫好側咀嚼の結果のみを娭討対象とした。

1) 咀嚼周期時間

表 5 は全被験者の各相扣よび周期時間を示す。

(1) 閉口相

BC を装着すると 3 例において有意に延長し， 舌面装置装着時には 3 例で有意に延長した。他の 被験者ではいずれの場合も有意差を示す変化は認 められなかった。

(2) 咬合相

$\mathrm{BC}$ を装着すると全例で延長し，そのらち2 例 で有意差が認められた。舌面装置装着時の変化は 被験者により異なり, 一定の傾向は認められなか った。

(3) 開口相

$\mathrm{BC}$ 装着時には被験者 $\mathrm{F}$ の延長傾向の夕に有意
差が認められた。占面装置装着時には被験者 $\mathrm{A}$ お よびCの短縮傾向のみに有意差が認められた。

(4) 周期時間

$\mathrm{BC}$ を装着すると被験者 $\mathrm{E}$ を除く 5 例で有意に 延長した。舌面装置装着時にも 4 例で延長し, そ のらち 2 例で有意差が認められたが，被験者 $\mathrm{A}$ ， Cでは逆に減少傾向を示した。

\section{2）下顎運動}

図10は典型例と思われる被験者 A，D前頭面 投影面上での下顎運動路を，IPより $1 \mathrm{~mm}$ およ び $3 \mathrm{~mm}$ 下方位の測定点について，側方滑走運動 路と重权合わせて示した。

(1) 閉口路

前頭面上では，装着前と比較して舌面装置を装 着すると $1 \mathrm{~mm}$ 抌よび $3 \mathrm{~mm}$ 下方位の測定点と 正中線との距離は減少する傾向が認められた。 $\mathrm{BC}$ 装着時にも被験者 $\mathrm{B}, \mathrm{D}, \mathrm{E}, \mathrm{F}$ では同様の 


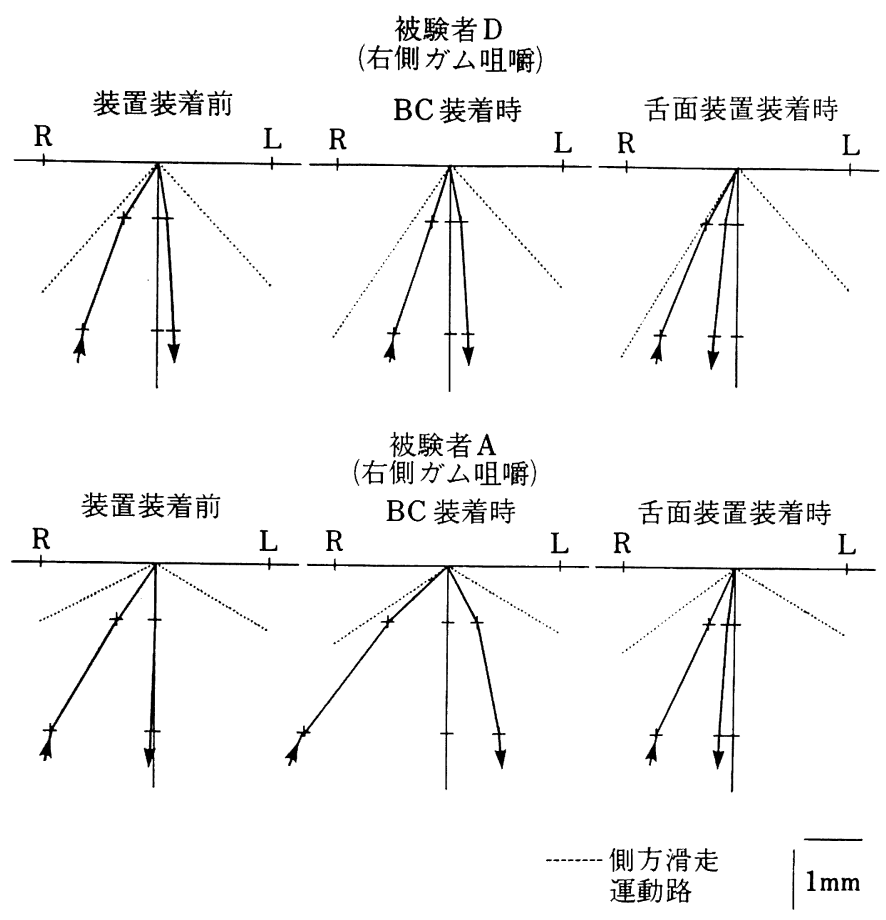

図10 ガム咀緭時の前頭面投影面上での下顎運動路

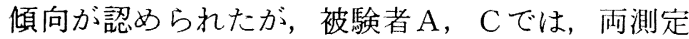
点と正中線との距離が逆に増加する傾向が認めら れた。

矢状面上では，両測定点に括いて $\mathrm{BC}$ および舌 面装置を装着すると，その変化量は少ないるの の，後方へ偏位する場合が多かった。しかし，被

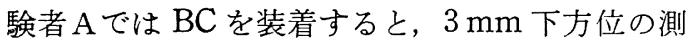
定点に招いて前方へ偏位した。

(2) 開口路

前頭面上では， $\mathrm{BC}$ を装着すると両測定点は， 被験者 $\mathrm{A}, \mathrm{C}, \mathrm{E}$ では非咀嚼側へ偏位し, 被験者 B では咀嚼側へ偏位した。舌面装置を装着すると， ほとんどの被験者において咀嚼側へ偏位した。

3）各笳の IP 比

(1) 閉口相

$\mathrm{BC}$ 装着時の 各筋の IP 比の変化は被験者によ り異なり，一定の傾向は認められなかった。しか し, 閉口相時間が有意に延長した被験者 $\mathrm{A}, \mathrm{B}, \mathrm{F}$
では, 各竻に打いて IP 比が減少する傾向が認め られ，その他の被験者では增加する傾向が認めら れた。

舌面装置装着時では，平衡側Mで増加するもの が多く，4例で有意差が認められたが，その他の 筋の IP 比の変化は被験者により異なり，一定の 傾向は認められなかった。

(2) 咬合相

図11は典型例と思われる被験者 $\mathrm{E} の$ 各筋の IP 比を示す。

$\mathrm{BC}$ を装着すると多くの筋に括いて増加傾向が 認められ，とくに平衡側 AT では全例で増加し， そのうち 4 例で有意差が認められた。

舌面装置を装着すると，平衡側 PT に打いて減 少傾向を示したが，その他の筋では増加する場 合が多く, 平衡側Mに招いては全例で增加し，そ のうち 5 例で有意差が認められた。BC 装着時と 舌面装置装着時とを比較すると, 平衡側 $\mathrm{M}$ 以外の 


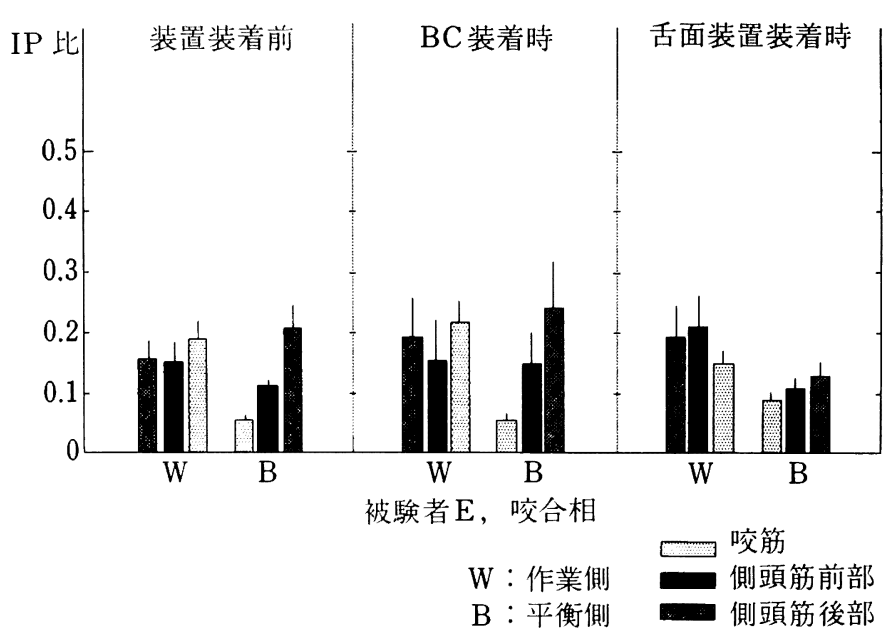

図11 ガム咀嚼時の各筋のIP比

筋において， BC 装着時の IP 比のほうが大きく なる場合が多かった。

4）作業側の活動比率

(1) 閉口相

M, AT, PT に打ける作業側の活動比率は, 全 例で平均すると装置装着前にそれぞれ， $69 \pm 6$

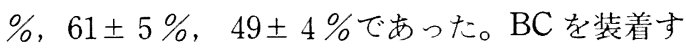

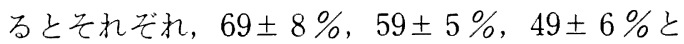
なり，いずれの筋においても有意差は認められな かった。

(2) 咬合相

M, AT, PT に打ける作業側の 活動比率は, 全 例で平均寸ると装置装着前にそれぞれ， $64 \pm 8$

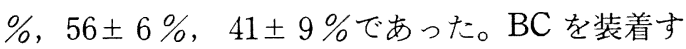

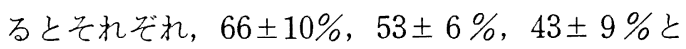
なり，いずれの筋に抢いても有意差は認められな かった。

\section{IV. 総括ならびに考察}

Schuyler ${ }^{15)}$, Glickmannn ${ }^{16)}$ らは側方咬合位に おける平衡側接触を咬頭干涉としてとら光，これ を否定している。一方，藍ら ${ }^{17)}$ は被験者 144 名を 対象に各下顎位に抢ける咬合接触状態を調查し, 側方咬合位において作業側と同時に平衡側大臼歯
部で咬合接触を示す被験例は $23.6 \%$ あったことを 報告しており，また長谷川18) は藍らの報告と同時 に，平衡側接触を示す咬頭は支持咬頭であり，か つ機能咬頭であることを根拠に，作業側と同時接 触するようなものについては是認する立場を取っ ている。しかしながら，作業側より強い平衡側で の咬合接触について，これを咬頭干渉とする考光 方18,19) には一般に異論のないところである。

本研究では作業側よりも強い平衡側での咬合接 触を平衡側咬頭干渉とし，その顎機能への影響を 明らかにするために，実験的な干渉装置を与え， 側方咬合位での最大咬みしめ, 側方滑走運動およ びガム咀嚼を行わせたときの閉口筋活動および下 顎運動を記録測定し検討した。

\section{1. 研究方法}

\section{1）被験者}

被験者には, 歯, 歯根膜, 顎関節, 咀嚼筋など に自他覚的に異常が認められず，またいわゆる個 性正常咬合を有し，下顎第二大臼歯に歯冠修復処 置を必要とする者を選択した。この要処置雪に対 してあらかじめ支台形成を行い，金銀パラジウム 合金で鋳造製作した暫間補綴物を仮着し， 1 力月 以上はそれを使用させたのち実験を行った。

2）実験的平衡側咬頭干渉装置 
臨床的に認められる平衡側咬頭干渉は, 作業側 ガイドの不良や平衡側歯列の急峻な彎曲が原因で 出現し，側方滑走運動過程のある段階で作業側歯 列を離開させる場合が多く，最後方臼歯の上顎舌 側咬頭と下顎煩側咬頭との間に好発する ${ }^{10) 。}$

咬合高径を変えないという条件下で，下顎大曰 歯の歯冠形態のみを変更し，同部位に実験的に平 衡側咬頭干渉を与えようとすると，その干渉の程 度は上顎臼歯舌側咬頭内斜面の形態に規制され る。本実験では側方咬合位での咬みしめ時には, 咬頭嵌合位で接触する部分は関与しないので, 図 1-Aに示す形態の干渉装置を用いたが，側方滑 走運動およびガム咀嚼時には，同部位の被蓋関係 が逆になるような干渉装置を別に製作し用いた (図 2-A)。

後者については干渉の程度が自由に規定でき， 咬頭嵌合位を変更することなく作業側よりも強い 平衡側接触が与えられるといら利点はあるが，当 該歯とその対合歯との接触関係が天然歯列の平衡 側咬頭干涉の場合と異なる。そこで，対合歯にも 修復処置を必要とした被験者 Bにおいて,この装 置と同程度の干渉を下顎大臼歯煩側咬頭内斜面と 上顎大曰歯舌側咬頭内斜面との間に与兄，ガム咀 嚼時の筇活動および下顎運動に対する影響を両装 置について比較した。本研究で対象とした測定項 目に関しては，装着前と比較した場合，両者で同 様の変化傾向を示し，干渉効果として差異はない と判断された。

3）筋活動の測定および分析

咬筋はその活動量と咬合力との相関が高く20), 咀嚼運動の prime mover の役割を担っており, また側頭筋は下顎の位置づけをするとともに ${ }^{21)}$, 咬合の障害に対してはきわめて鋭敏であると考光 られている22)。以上の理由から本研究では咬筋と 側頭筋を被験筋とした。

導出方法としては，機能時の筋の全体的な活動 を把握するため, 表面電極を用い双極導出を行っ た。

筋活動の分析方法としては, 定量的にとらえる 目的からその有効性に一定の評価が得られている
積分値を指標として用い，さらに被験者間，ある いは各笳間の活動状況の比较検討をしやすくする ために，積分値から IP 比を求めた ${ }^{12 \sim 14) 。 ま た ， ~}$ 各被験運動時に左右どちらの筋が主として活動し ているかを検討するために，作業側の活動比率を 求めた。

4）下顎運動の測定

下顎運動の測定方法として, 最近では磁気や LED 受光素子を応用した方法が広く一般に用い られている。シロナソグラフは下顎切歯点部に付 与したマグネットの動きをセンサでとらえ，下顎 運動を測定するものであり, 被験者の違和感が少 ないこと, 三次元で計測できること, 操作が簡便 であることなどの利点があるため, 本研究ではこ の装置を使用した。シロナソグラフの出力特性に ついては, 分解能は $0.3 \mathrm{~mm}$, 一辺の長さ $30 \times 30$ $\times 50 \mathrm{~mm}$ の直方体の面上での 最大䛊差は $10 \%$ で, その内部ではさらに小さくなると報告されて特 $\eta^{23)}$, 本研究でも同様の結果が得られた。

下顎運動の測定に際しては, マグネットのセン サに対する位置を，付属のアタッチメントにより シロナソグラフの歪みの少ない範囲を有効に使う ように設定し, 被験者の口腔内に各装置を装着す るときにはセンサ部を動かさないよう留意した。

\section{2. 研究結果}

1）側方咬合位での最大咬みしめ

咬みしめ時の咀嚼筋活動について多くの報告が なされている。咬筋および側頭筋は, 天然歯列の 場合, 咬頭嵌合位で咬みしめを行わせると最大の 筋活動を示し，支持域や下顎位の変化に伴いその 活動状態が変化することが示されている24 29)。

MacDonald ${ }^{26)}$, 古屋 ${ }^{27)}$ らは側方咬合位で咬み しめを行わせると，咬頭嵌合位で咬みしめたとき と比較して，いずれの筋でも活動の減少が起こ り，とくに平衡側の側頭筋に敃いてその傾向が顕 著であると述べている。本研究に拈いても同様の 傾向が認められ，側方咬合位での咬みしめ時の咬 筋の IP 比は, 作業側で0. 39, 平衡側では0.49 と やや高くなるが，側頭筋前部の IP 比は，作業側 で0.42, 平衡側で 0.16 , 側頭筋後部の IP 比は, 
作業側で0.41，平衡側で0.16 と，側頭筋では平衡 側でかなり低い值を示した。

一方，一部の歯に干渉装置などをつけた場合に ついては, Belserら ${ }^{9)}$ は作業侧の大日雨および犬 歯と平衡側の大臼歯のそれぞれに，他の歯の接触 を失わせるような装置を装着し，側方咬合位での 咬及しめを行わせている。これらの装置を作業側 の大臼歯および犬米に装着しても，各筋の活動の 大小関倸には変化は認められなかったが，平衡側 大臼歯に装着する之，咬筋の活動の左右間の大小 関係は不変であるのに対し，側頭筋のそれは顕著 に変化したと述べている。

本研究でも, 筋活動を作業側, 平衡側の別に検 討すると，この結果と同様にWC や舌面装置を装 着しても，いずれの筋においても作業側の活動比 率は変化しなかったが，BC を装着すると咬筋の 作業側の活動比率は変わらないのに対し，側頭筋 の作業側の活動比率は減少した。

礒20)は、シーネを装着させた状態で側方位で咬 みしめを行わせると, 側頭筋は支持点のある側, 寸なわち支持側で䀺位に活動し，咬筋は支持側， 非支持側にかかわらず両側性に活動したと述べて いる。本研究の場合にこれを当てはめて考兄る と，WCを装着しても，装置装着前と支持側が同 じであるため，各筋の活動の作業側，平衡側の大 小関係には大きな変化は起きない。また， $\mathrm{BC}$ を 装着すると平衡側が支持側となるため, 平衡側の 側頭筋の活動が増大することになり，咬筋は支持 側の影響を受けにくいためそのよらな変化を示さ ないといらことになる。しかしながら，WCにつ いてはともかく, 図 6 の BC 装着時の側頭筋の活 動をみると，支持側である平衡側の活動は，装置 装着前よりは明らかに増大するが，減少を示した 非支持侧である作業側の活動よりも優位になった とはいえない。

そこで，筋活動を支持側，非支持側との関係か ら検討を試みた。罒12に，下顎右側第二大目歯に WC, BC を装着した場合の，典型例と思われる被 験者 $\mathrm{A}$ の側方咬合位での咬みしめ時の各筋の IP 比を支持側，非支持側別に示した。この場合，被
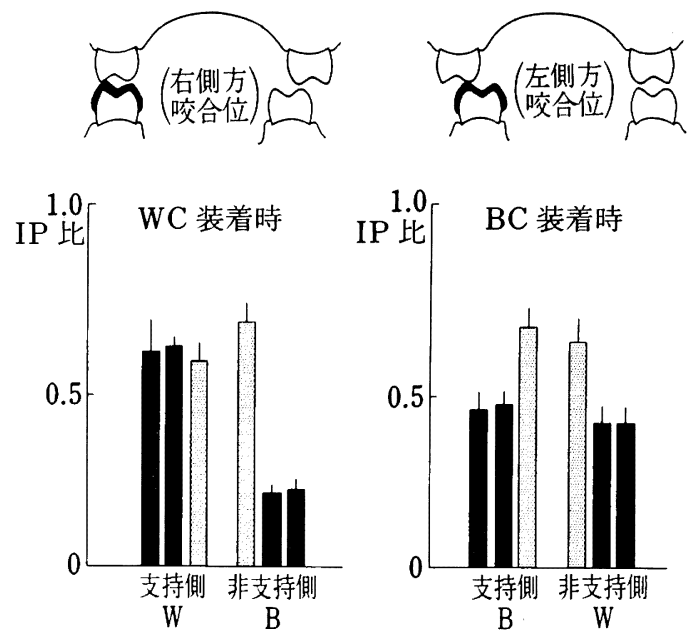

$\mathrm{W}:$ 作業側

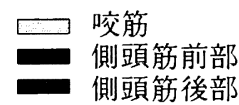

図12 側方咬合位での最大咬みしめ時の各筋のIP 比（被騟者 A)

験者は WC 装着時には右側方咬合位で， BC 装着 時には左側方咬合位で咬みしめを行っているが, 下顎を支持するのは常に右側になる。

WC 装着時には非支持側側頭筋の筋活動は, 支 持側のそれと比較してかなり小さく，この傾向 は, 装置を装着してない天然歯列の場合と同様で ある。しかし，BCを装着し左側方咬合位をとら せると，非支持側の活動が増大し支持側のそれが 減少するようになった。その結果, 非支持側の活 動は支持側の活動と同程度となった。一方，咬筋 は支持点の位置にかかわらず両側性に活動する が，わずかながら平衡側で強い活動が認められた ため， BC 装着時には逆に 非支持側の活動が小さ くなった。しかし，非支持側の側頭筋の活動の増 大と比較すると，その減少量は小さく，支持側で の筋活動に対して，非支持側での筋活動は全体と しては増大した，といらことになる。同様の傾向 は他の被験者においても認められた。これについ て礒 ${ }^{20)}$ 述べているが，不安定な平衡側での咬み しめに対して，咀嚼筋は下顎の保持などの間接的 な作用として，より多く活動する必要が生じ，作 

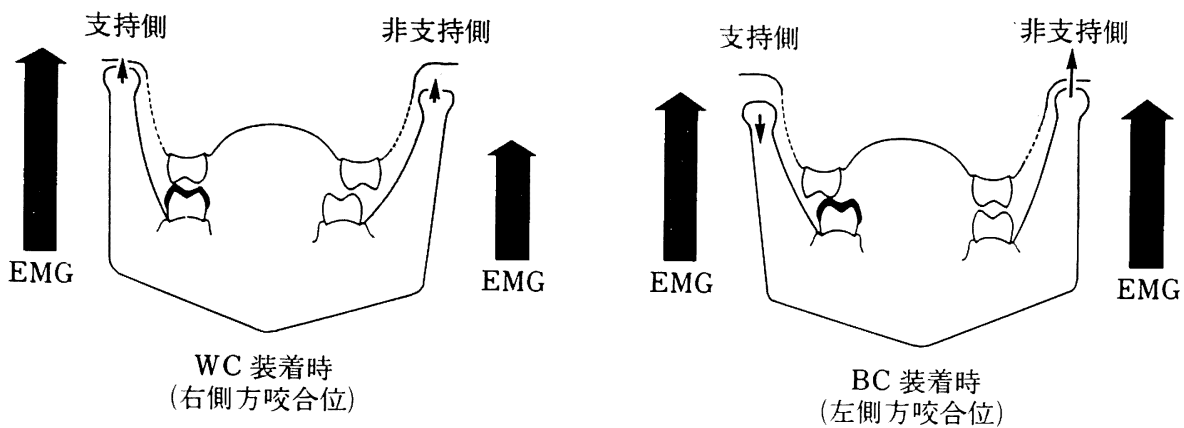

図13 筋活動と顆頭の上下的な变位（模式図）

業側である非支持側の活動が増大したと考えられ る。

これに関して，WC装着時の筋の活動状態は， 生体のバイオメカニクスに 合致するが, BC 装着 時の非支持側における筋活動の増大は, その点で 問題があると考兄られる。つまり，これは一つに は支持点との距離が長いことと相俟って, 非支持 側つまり作業側の顆頭を上方へ変位させ, 顎関節 部に著しく大きい圧力を加えることになり，支持 側つまり平衡側の顆頭を下方へと引き下げ，顎関 節部には Krogh-Poulsen ら ${ }^{30)}$ が述べる intercondylar space を広げるような作用を及ぼすことが 推察される（図13）。事実，実験中に，BC を装 着して咬みしめを行わせると，作業側の下顎歯列 が大きく上方へ変位する様相が肉眼的に 観察さ れ，作業側顆頭の上方への変位がうかがわれた。

このように, 平衡側の咬頭干涉によって非支持 側, つまり作業側の筋活動が全体的に増大し, 顆 頭位にもその影響がうかがわれたことは，顎機能 異常の原因因子とされる平衡側咬頭干渉の作用機 序を考えるらえで有効な示唆を与えるものと考党 られる。

2）側方滑走運動

(1) 側方滑走運動時の筋活動

側方滑走運動時の咀嚼筋活動については多くの 報告がなされている。咬筋と側頭筋を対象とした 報告では，咬頭嵌合位から側方咬合位までの滑走 運動は, 主として作業側の側頭笳後部の作用とし て，また側方咬合位から咬頭嵌合位までの滑走運
動は, 両側の側頭筋と咬筋の作用として行われる ことが示されている12,31,32)。本研究に拈いても同 様の傾向が認められ, 往路では, 作業側の側頭筋 後部で強い活動が認められ, 復路では, 咬筋は両 側でほぼ同程度であり，側頭筋は作業側で優位に 活動する傾向が認められた。

(2) 平衡側咬頭干渉の筋活動への影隌

(1) 往路

曽根田 ${ }^{12)}$ は，犬歯部誘導面の傾斜角度が急にな ると，側方滑走運動時の咬筋之側頭筋後部の活動 量が減少したと述べている。本研究でも舌面装置 装着時に同様の傾向を示すものも認められたが, 傾斜角度の变化が $10^{\circ}$ と小さいため, 曽根田のよ らな顕著な傾向は認められなかった。

また，BCを装着すると作業側側頭筋後部の活 動が増大寸る傾向が認められ，またその活動比率 も増加する傾向が認められた。

いずれの被験者も $\mathrm{BC}$ 装着時に括いて最も滑走 運動しにくいと述べていたが，指定した運動を遂 行するのにより多くの筋活動を必要とし, それが 側方滑走運動の往路に主として関与する作業側側 頭筋後部の活動の増大として現れたものと推測さ れる。

(2) 復路

また，曾根田 ${ }^{12)}$ は， 犬歯部誘導面の傾斜角度が 总になった場合, 復路では作業側と平衡側の活動 比率には一定の変化傾向は認められなかったと述 ベており，本研究でも舌面装置を装着したときに は，作業側の活動比率に有意な変化を示すものは 
少なかった。岡部32)は作業侧でのガイド部位の違 いが咬筋物よび側頭筋後部の筋活動に及ぼす影響 を検討し, 本研究の復路に相当する閉口相では, 犬歯部よりも第二大臼齿部でガイドする場合のほ らが作業側 2 筋の活動比率が大きくなる傾向があ ると述べている。

本研究では, $\mathrm{BC}$ を装着すると, 装着前, 舌面 装置装着時のいずれと比較しても，作業側の活動 比率が減少し, 作業側の筋活動の優位性が失われ る傾向が認められた。またその傾向は側頭筋にお いて顕著であった。

$\mathrm{BC}$ 装着後の側頭筋後部の活動の変化について は, 復路は主として平衡側の側頭筋後部の作用に よって行われるとみられるため, 往路で作業側側 頭筋後部の 活動が増大したことと同様の 理由か ら, 平衡側側頭筋後部の活動が増大し, 結果的に 作業側側頭筋後部の活動の優位性が失われたと考 えられる。しかしながら, 本研究では装置装着前 および舌面装置装着時において, 側頭筋後部の活 動を作業側と平衡側とで比較した場合, むしろ作 業側で優位な活動が認められた。この点に関して は, 滑走運動を中程度の力を加光ながら行らよう 指示したことと関連していることが推测される が，今後の検討課題である。

また，側方咬合位から咬頭嵌合位への滑走運動 は, 下顎を挙上する方向の運動であり, 被験者が 指定ど特りに，つまり中等度の力を加えながら， 滑走運動を行おうとする場合には，側頭筋前部は 下顎に対して咬みしめの場合と類似した垂直方向 へと力を加えることになる。そのため, 滑走運動 をガイドする部位が咬みしめ時の支持点のように 働き, 装置装着側である平衡側の活動が装着前よ り優位になったと考えられる。

ここで，装置装着側を支持側としてとらえ，支 持側と側頭筋前部の筋活動との関係を検討する と, 側方滑走運動の復路では, 非支持側, つまり 作業側の筋活動が支持側と同等あるいはそれより 大きくなる場合と, 非支持側の筋活動が支持側の それと比べて小さくなる場合とが認められた。前 者については, 側方咬合位での咬みしめの場合と
同椂に考えられるが，後者については，側方滑走 運動では咬みしめと比較して下顎に加わる力が小 さく，不安定となった下顎を保持するような筋の 作用を必要とせず，そのため，非支持側での活動 が小さくなる場合があったと考兄られる。

このような被験者間の差異については, 滑走運 動時の誘導部位での力の規定を中等度としたもの の, これは被験者の感覚に任せて拉り, 被験者に よってその大きさにはばらつきがあり，その影響 によるものと推測される。

総じて, 平衡側咬頭干渉は, 往路では作業側側 頭筋後部の筋活動を増大させ, 復路では側頭筋の 活動に対して作業側の活動の優位性を失わせるよ らな作用をもつと推測される。

3）ガム咀嚼

(1) 時間

周期時間は， BC を装着すると延長する傾向が 認められたが，舌面装置を装着したときにも同様 の傾向が認められた。周期時間の延長は各装置の 装着が咀嚼運動の円滑さを損なったことに起因す ると考光られる。

咀嚼周期中の各相の時間については, 舌面装置 を装着しても一定の変化傾向は認められなかった が， BCを装着すると咬合相時間が延長する傾向 が認められた。この傾向は下顎運動路の変化と関 連していると考觉られた。

(2) 筋活動

閉口相に怙ける筋活動は, $\mathrm{BC}$ を装着すると閉 口相時間が有意に延長した被験者 $\mathrm{A}, \mathrm{B}, \mathrm{F}$ では小 さくなる傾向を示し，その他の被験者では大きく なる傾向を示した。本研究では，1秒間当たりの 筋活動の積分值から IP 比を求め筋活動の 指標と したが，ここで閉口相中に要した積分値について 検討すると，装置装着前と $\mathrm{BC}$ 装着時とでほぼ同 程度であった。

咬合相に打ける筋活動は， BC および舌面装置 を装着すると多くの筋で大きくなる傾向が認めら れた。また， $\mathrm{BC}$ 装着時と舌面装置装着時とを比 較すると BC 装着時のほうが大きくなる傾向が認 められた。 
各筋の活動の大小関係については, Schaerer7), De Boever ${ }^{8)}$ は平衡側咬頭干渉装置を装着しても 変化しなかったと述べているが，本研究でも閉口 相, 咬合相ともに, いずれの筋でも作業側の活動 比率には顕著な変化は認められなかった。

（3）下顎運動

ガム咀嚼では下顎歯が上顎歯に対して滑走運動 する率が高く，切歯部での記録では $2 \mathrm{~mm}$ 前後の 滑走運動があるといわれている33)。本研究では, 舌面装置および BC を装着すると，それに伴い側 方滑走運動路の 前頭面上での 傾斜角度が急にな り，閉口路はそれらに機械的に制約された。その 結果, 舌面装置装着時の運動路を前頭面上で検討 すると, 閉口路は正中へ近づき，開口路は咀嚼側 へ偏位し, 閉口路と開口路との距離が縮小する傾 向が認められたが， BC 装着時には，舌面装置装 着時と異なる变化傾向を示すものが認められた。 すなわち，被験者 $\mathrm{A} ， \mathrm{C}$ では， BCにより制約さ れているにもかかわらず，閉口路が咀夁側へ偏位

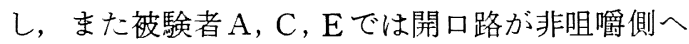
大きく偏位する傾向が認められた。なお, 開口路 の偏位は, 咬頭嵌合位付近の開口路に装着前と比 ベて多くの滑走運動が認められたことと関係があ ると考えられた。

早期接触が存在すると $\gamma$ 系を介する反射が起こ り，無意識のうちに運動障害のある 箇所で歯を すり合わせたり咬みしめたりして，これを除去し ようとするといわれているが34)，被験者 $\mathrm{A}, \mathrm{C} の$ $\mathrm{BC}$ 装着時の閉口路の変化, つまり咀嚼側への偏 位にはこうした ない。しかしながら，被験者が意識的に咬み方を 変えた可能性も否定できない。この点については 今後の課題である。また, 被験者 $\mathrm{A}, \mathrm{E}, \mathrm{C}$ の開口 路が非咀嚼側へと偏位する傾向を示したことにつ いては以下のような原因が考兵られる。BC の装 着により作業側臼歯部での臼磨運動はかなり制限 を受けている。しかし，咬合相の後期から開口相 の初期にかけては BC は関与しないので臼磨運動 を行うことは可能である。そのため, 開口相に拉 いて接触滑走が認められたのであろう。そして,
咬合相でこのような罒磨運動が行われたことによ って, 咬合相時間が延長し, 筋活動も増大したも のと考学られる。

鯉㴊 ${ }^{14)}$ は, 咬頭嵌合位について実験的に早期接 触を付与し咀嚼させると，それを避けようとする 運動路が現れるようになり，また咬合相時間が短 縮し, 咬合相における筋活動量が減少することを 報告している。咬頭嵌合位が早期接触によって損 なわれれば，円滑な臼磨動作は行えないため，そ のような結果が得られたと推察されるが，咀嚼中 に平衡側での接触が起こっても, 咬頭嵌合位に支 障がなければ，その付近での臼磨はある程度可能 であろら。

このように, 被験者によっては BC 装着時に特 異な咀嚼経路の変化を呈するものもあったが, 全 体としては平衡側咬頭干渉とガ么咀嚼時の筋活動 および下顎運動との間には明確な関連は認められ なかった。ただし，これは装置装着直後の記録で あり，長時間経過した場合の状沉についてはさら に検討の必要がある。

以上述べたように, 本研究結果より平衡側咬頭 干渉は，側方咬合位での咬みしめや側方滑走運動 時に顎関節部に加わる力を変化させる可能性が示 㖫された。本研究では咬筋と側頭筋前部および後 部の活動のみを検討対象としたが，実際にはこれ らの動作に際して他の多くの筋も関与しており, それらを含めた検討をすることにより，平衡側咬 頭干渉の顎機能に対する影響がさらに明確にされ ると考えられる。

\section{V. 結 論}

平衡側咬頭干渉が咀嚼筋（咬筋, 側頭筋前部, 側頭筋後部）の機能拈よび下顎運動に及ぼす影響 を明らかにするために，6人の被験者について下 顎第二大臼雬に実験的平衡側咬頭干渉装置 BC 与え, また比較のため, 作業側犬歯, 第二大臼歯 にもそれぞれ，舌面装置，干渉装置 WC を付与 し，側方咬合位での最大咬みしぬ，側方滑走運動 を行わせて筋活動を，またガム咀嚼を行わせて筋 活動と下顎運動を記録測定し, 実験的咬頭干渉と 
の関係を検討した結果，以下のような結論を得 た。

1. 側方咬合位での咬及しめの場合,

1）装置装着前，舌面装置装着時拈よび WC 装 着時には, 咬筋は両側性に活動し, 側頭筋前部拈よ び後部は作業側で優位に活動する傾向を示した。

2） $\mathrm{BC}$ 装着時には，咬肸は装置装着前之同様に 両側性に活動したが，作業側側頭筋前部および後 部の活動の優位性は失われた。

3）支持側を基準にすると， BC 装着時の側頭 筋前部および後部の筋活動は, 他のいずれの場合 と比較しても支持側で小さく，非支持側で大きく なる傾向を示した。

2. 側方滑走運動の場合,

1）往路では，装置装着前には，被験 6 筋のな かで，作業側の側頭筋後部の活動が最大となる傾 向が認められた。また, 舌面装置および BC 装着時 にも同様の傾向が認められたが， BC 装着時には 同笳の活動がさらに增大する傾向が認められた。

2）復路では，装置装着前拈よび舌面装置装着 時には，側頭笳前部および後部の活動は作業側で 優位に活動する傾向を示した。しかし， BC 装着 時には，作業側側頭筋の活動の優位性が失われる 傾向が認められた。

3. ガム咀嚼の場合,

1）装置装着前，舌面装置装着時のいずれと比 較しても， BC 装着時の咬合相時間は延長し，同 相にお汁る筋活動は增大する傾向を示した。

2）舌面装置装着時の咀嚼経路は，装置装着前 と比較して閉口路が正中へ近づき, 開口路が咀嚼 側へ偏位する傾向を示した。

3） $\mathrm{BC}$ 装着時の咀嚼経路は, 装置装着前と比較 して舌面装置装着時と同樣の変化傾向を示す場合 と, 閉口路が咀嚼側へ偏位し, 開口路が非咀嚼側 へ大きく偏位する場合が認められた。

4. 平衡側咬頭干涉は, クレンチングあるいは グラインディングのような非機能的な動作の際に 側頭筋活動に異常な活動様相をもたらす可能性が 示唆された。

\section{謝辞}

稿を終えるに臨み，ご愍篎なるご指導とご校閲を賜 りました篮 稔教授に讙んで感謝の意を表します。ま た，終始格別のご援助，ご教示をいただきました医用 器材研究所精密機械部門, 高久田和夫助教授に深く感 謝いたします。さらに，懇切なるご指導とご教示をい ただきました米科補緅学第 1 䍀座，水谷紘陆師に心か らお礼申しあげます。また本研究に際し，ご援助，ご 協力いただきました浰科補経学第 1 講座の諸先生方, ならびに被験者の皆様に厚く抢礼中しあげます。

なお，本論文の要旨の一部は，平成元年度日本補紃 蕋科学会関東支部学術大会（1990年 2 月 24 日）飞打い て発表した。

\section{文献}

1) Schuyler, C. H. : An evaluation of incisal guidance and its influence in restorative dentistry. J. Prosthet. Dent. 9 : 374-378, 1959.

2) Ramfjord, S. P. : Dysfunctional temporomandibular joint and muscle pain. J. Prosthet. Dent. 11 : 353-374, 1961.

3）中村公雄, 他 : 顎関節症患者の上下䫈米牙接触 関係に関する研究。補綴誌 19：481-495, 1976.

4）関 秀孝：颔関節症の補䋂学的研究 第 1 解顎 関節症患者の咬合に関する研究. 口病誌 35 : 213-227, 1968.

5) Posselt, U. : The temporomandibular joint syndrome and occlusion. J. Prosthet. Dent. 25: 432-438, 1971.

6) Shore, N. A. : Temporomandibular Joint Dysfunction and Occlusal Equilibration (2nd ed.). Philadelphia, Tronto, 1976, J. B. Lippincott Co., 1-376.

7) Schaerer, P., Stallard, R. E. and Zander, H. A. : Occlusal interferences and mastication. : An electromyographic study. J. Prosthet. Dent. $17:$ 438-449, 1967.

8) De Boever, J. : Experimental occlusal balancing-contact interference and muscle activity. Parodontologie $23: 59-69,1969$.

9) Belser, U. C. and Hannam, A. G. : The influence of altered working-side occlusal guidance on masticatory muscles and related jaw movement. J. Prosthet. Dent. 53 : 406-413, 1985.

10）河野正司, 鳥山秀行, 吉田恵一, 小林 博: 平 衡側咬頭障害の発現機構に関する一考察. 補緅 誌 $32: 505-513,1988$. 
11) Lewin, A. : Electrognathographics, Atlas of Diagnostic Procedures and Interpretation. Chicago, London, Berlin, Tokyo, Rio de Janeiro, 1985, Quintessence Publishing Co., 11-24.

12）曾根田兼司：上顎犬萪舌面の傾斜角度の違いが 咀嚼筋活動に及ぼす影響。 口病誌 56 ：162$181,1989$.

13）水谷 紘, 篠ヶ谷龍哉, 曽根田兼司, 礒 和 博, 藍 稔: 歯の接触関係が咬筋, 側頭筋の 活動に及ぼす影響 第 1 報 総活動量と咬頭嵌 合位における最大咬みしめ值に対する比率（IP 比). 補緅誌 33:1062-1071, 1989.

14）鯉㴊秀明：習慣的閉口運動における実験的早期

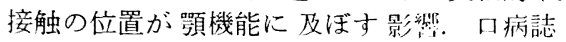
$57: 31-52,1990$.

15) Schuyler, C. H. : Factors contributing to traumatic occlusion. J. Prosthet. Dent. 11 : 708-715, 1961.

16) Glickmann, I. : Clinical Periodontology (4th ed.). Philadelphia, London, Toronto, 1972, W. B. Saunders Co., 852-889.

17）藍稔, 中野雅德：颚口腔采の形態, 機能に 関一る臨床的調查第 2 報咬合について。補 緅誌 $19: 385-390,1975$.

18）長谷川成男：咬合学序説 機能的咬合面形態を 求めて. 東京, 1988, 医渊薬出版, 231-234.

19）藍稔：顎機能異常一咬合からのアプロー 千. 東京, 1983, 医蔽薬出版, 1-322.

20）礒和博：支持点の位置が咬合力, 咀嚼筋活動 に及ぼす影郘に関する研究。口病誌 49 : 168190, 1982.

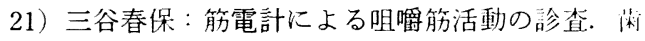
科ジャ一ナル $16: 307-313,1982$.

22) Ramf jord, S. P. and Ash, M. M. : Occlusion (3rd ed) . Philadelphia, London, Tronto, Mexico City, Rio de Janeiro, Sydney, Tokyo, 1983, W. B. Saunders Co., 1-265.

23) Hofmann, V. M. and Pröschel, P. : Unterkief- erdynamik und Kaumuster von Totalprothes enträgern und Vollbezahnten-Eine Pilotstudie. Dtsch. Zahnärztl. Z. 37 : 763-771, 1982.

24) Wood, W. W. and Tobias, D. L. : EMG response to alteration of tooth contacts on occlusal splints during maximal clenching. J. Prosthet. Dent. 51 : 394-396, 1984.

25) MacDonald, J. W. C. and Hannam, A. G. : Relationship between occlusal contacts and jawclosing muscle activity during tooth clencing: Part I. J. Prosthet. Dent. 52 : 718-729, 1984.

26) MacDonald, J. W. C. and Hannam, A. G. : Relationship between occlusal contacts and jawclosing muscle activity during tooth clenching : Part II. J. Prosthet. Dent. 52 : 862-867, 1984.

27）古屋元之：咬合力と咀緭筋の筋放電との䦛倸に ついて実験的研究 第 2 報 左右側的条件に ついて. 采科学報 84:1367-1422, 1984.

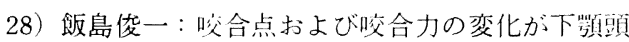

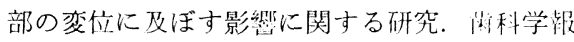
$83: 841-865,1983$.

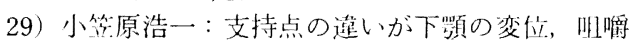

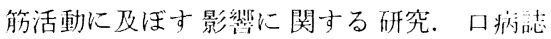
53 : 81-101, 1986.

30) Krogh-Poulsen, W. G. and Olsson, A. : Occlusal disharmonies and dysfunction of the stomat. ognathic system. Dent. Clin. North. Am. 10 : 627-635, 1966.

31）六車寿男：咀嚼筋筋電图の補綏学的分析に関寺 万研究. 料科医学 28:615-650, 1965.

32）臹部良博：下颚誘導部位の相違が咀嚼筋活動に 久ぼす影響について。病誌 53 : 102-128, 1986.

33）監稔：切蔯点部に抢ける咀緭運動の解析. 補緅誌 6:164-200, 1962.

34) Körber, K. : Zahnärztliche Prothetik Bd. I : Funktionslehre, Gnathologie, Traumatologie. Stuttgart, 1975, G. T. V., 184-186. 